THE VIOLENT GOD OF THE BIBLE:

\title{
A STUDY ON THE HISTORICAL BACKGROUND AND ITS IMPACT ON THE DISCUSSION ON HUMAN DIGNITY ${ }^{1}$
}

\author{
Klaas Spronk \\ Protestant Theological University
}

Kampen

\begin{abstract}
This article seeks for a good method to use the Bible in a fruitful way in discussions about religion and violence. First some general remarks are made on the hermeneutics of sacred texts. Then the discussion is presented about the assumed direct relation between monotheism and violence, evaluating the positions of Assmann and Albertz. Much attention is paid to the image of Yhwh as a jealous god with jealous (zealous) followers. It can be demonstrated that the picture of a violent God is much influenced by historical circumstances. Already within the Old Testament the central confession about Yhwh in Exodus 34:6-7 describing him as both merciful and violent has been applied differently, depending on the changing situation. As a conclusion some indications are given about the way the Bible can act as an agent of change.
\end{abstract}

Keywords: Violence, Hermeneutics, Monotheism, The jealous God, Revenge

\section{Introduction}

\section{Some preliminary remarks on the use of Bible in discussions about violence}

It is a common and frustrating experience that, although the Bible is accepted by many as normative, in situations of stress and violence biblical texts are usually not used to open up discussions but to close them by using specific texts to defend one's own views and convictions. It appears to be very difficult to avoid that Biblical texts are used primarily to support an already taken standpoint. So when we want to take the Bible seriously we should begin with asking ourselves whether we are aware of the criteria that we use and that are used by others in selecting the biblical text one wants to listen to or to preach from in a specific situation. Very often the application of biblical texts appears to say more about the user than about the texts (mis)used. Therefore, Collins in his excellent survey of the issues at stake here, rightly calls for honesty of the biblical interpreter. ${ }^{2} \mathrm{We}$ should on the one hand firmly take as our starting point that, as Barr eloquently described it, "the command of consecration to destruction is morally offensive and has to be faced as such". ${ }^{3}$ On the other

\footnotetext{
Thanks are due to Hendrik Bosman for his critical and stimulating response to the first version of a paper read on this subject in Stellenbosch, 18 June 2009.

2 JJ Collins, 'The Zeal of Phinehas: The Bible and the Legitimation of Violence', JBL 122 (2003:3-21; esp. (20).

3 J Barr, Biblical Faith and Natural Theology, Oxford: Clarendon 1993, 218; quoted by Collins, 'The Zeal of Phinehas', (20).
} 
hand Collins rightly states that it should be acknowledged that the Bible is "no infallible guide to ethical matters" and that the stories it tells are no "paradigms for human action in all times and places".

One could say that it takes a true prophet (in the sense of one who knows about the living word of God) to use the right sacred text in the right situation at the right moment. A good biblical example of this is the story of Jeremiah versus Chananja (Jer 28). These two men, who both claim to speak in the name of God, come with contradictory prophecies, but they can both defend their words with reference to previous, authoritative traditions. For their hearers it must have been very difficult to decide who of them was right. History proved Jeremiah to be the true prophet, but his contemporaries missed our canonical confirmation and were facing a difficult choice. Reading the Bible and applying it to our situation is not much different: using the Bible does not guarantee that it will be easy to understand what is right and - usually more difficult - to act accordingly.

One good thing you can say about texts describing violence by, or in the name of God is that these texts can be of help when trying to open up a discussion about violence and to find new perspectives. In previous contributions to the Stellenbosch Kampen Project about human dignity, trying to see it in the light of the Bible, I discussed a number of gruesome stories in the book of Judges. ${ }^{4}$ Stories like these can at least help to take seriously the problem of violence. In the canonical context they function as the call for a right king who brings justice and who protects the weak. As part of our sacred texts they also invite the reader not to look away from similar atrocities in their own situation, to take courage to analyze and to fight them.

The canonical context should also be taken seriously when it comes to describe the image of God. The Bible is handed over to us in a tradition which has as its basic conviction that the God this book talks about is a good god. He created mankind not to serve him. The ideal earth as the kingdom of God is a good place for humans. This positive standpoint concerning God indicates that biblical texts describing God as violent and describing violence performed in the name of God are regarded as problematic, but also that the source of the problem is probably not God but man. When God uses violence it is usually to punish transgressors or to bring liberation. Most of the biblical stories about this subject are meant to reflect upon man and his sinful behavior in the past and then inevitably also to mirror the life and thought of the present reader. Applying them to one's present situation and using them as indication that in a given situation violence can be used in the name of God is dangerous and may be blasphemous. It can also distract from the purpose of these sacred texts to let the reader reflect on his own life and responsibilities.

\section{Monotheism as a Cause of Violence?}

Some scholars see a direct relation between monotheism and violence. ${ }^{5}$ Especially the German Egyptologist Assmann has put in the last ten years much effort in his case to prove that the monotheistic claim that one can and must decide between true and false religion (he

4 Cf K Spronk, "The Human Being as the Image of God and Human Beings Slaughtered in the Name of God: Biblical Subversion of Ancient and Modern Concepts of Human Dignity", Scriptura 95 (2007), 195-201; cf also K Spronk, "Sanctioning Samson: Do Old Testament Stories about Violence Make Sense Today? Some Answers from the Perspective of Redaction Criticism and History of Research," in: H de Wit and GA West (eds.), African and European Readers of the Bible in Dialogue: In Quest of a Shared Meaning, Leiden: Brill, 2008, 169-180.

5 Cf RM Schwartz, The Curse of Cain: The Violent Legacy of Monotheism, Chicago: University of Chicago Press, 1997. 
defines it as 'the Mosaic Distinction') is the primary cause of religious violence. ${ }^{6} \mathrm{He}$ is motivated by a concern about "the wave of religiously motivated violence that is presently descending on the world". He sees his work in line with that of David Hume, who "may have been right after all when he postulated a connection between monotheism and violence in chapter 9 of The Natural History of Religion (1757)". 7 Assmann can point to the fact that the Bible tells us that the breakthrough of monotheism is associated with violence. The history of the victory of monotheism is a history of extreme violence in a bloody series of massacres, like the extremely harsh punishment following the veneration of the golden calf (Ex 32) and the murder of hundreds of Baal priests after being defeated by Elijah (1 Ki 18). Assmann does not claim that monotheism is inherently or structurally violent or intolerant. He merely points to the facts showing that there is a strong tendency within monotheism towards violence and intolerance. ${ }^{8}$ The heart of the matter is that in the Bible this one god is pictured as a jealous god, who strictly distinguishes between friend and foe. ${ }^{9}$

Assmann's theory is simple and perhaps therefore attractive or shocking. According to Collins it is 'no doubt, too simple', ${ }^{10}$ but Collin's article also shows that it appears to be very difficult to offer a convincing alternative based on the authority of the Bible. The observation that "polytheism can be used to legitimate violence just as easily as monotheism" " does not solve the problem, because this does not prove that monotheism is usually rightly regarded as the better option. According to Collins a "promising strategy is to note the diversity of viewpoints within the Bible, and thereby relativize the more problematic ones". ${ }^{12}$ But he adds that a selective reading, emphasizing for instance the biblical command to love one's enemies, "does not negate the force of the biblical endorsements of violence".

In a recent article Albertz follows this path of relativizing by pointing to the historical context of the rise of monotheism in ancient Israel. ${ }^{13} \mathrm{He}$ admits that there is a dangerous potential of violence in monotheism, but in his view it only comes to an outbreak when religious power is united with political power. In the history of Israel monotheism became more and more the religion of powerless people and therefore lost its violent character. According to a growing majority in scholarly research the religion of ancient Israel only gradually became monotheistic. An important step towards the belief in one god, taking the place of other gods known in the region, was the violent rebellion against the Omri dynasty. It was lead by Jehu and initiated by the prophet Elisha. The stories in 1 Kings describe it as religiously motivated violence, which started with Elijah fighting against the priests of Baal

6 One of the first books in which he presented his case is J Assmann, Moses the Egyptian: The Memory of Moses in Western Monotheism, Cambridge MA: Harvard University Press, 1997. See also P Walter, J Assmann, Das Gewaltpotential des Monotheismus und der dreieine Gott, Freiburg: Herder, 2005. Recently he published Of God and Gods: Egypt, Israel, and the Rise of Monotheism, Madison: University of Wisconsin Press, 2008; see especially chapter 6: "No God but God: Exclusive Monotheism and the Language of Violence" (106-126).

Assmann, Of God and Gods, 109.

Assmann, Of God and Gods, 110.

Assmann, Of God and Gods, 114.

Collins, The Zeal of Phinehas, 3.

Collins, The Zeal of Phinehas, 3-4.

Collins, The Zeal of Phinehas, 19.

13 R Albertz, "Monotheism and Violence: How to Handle a Dangerous Biblical Tradition", in: J van Ruiten, JC de Vos (eds.), The Land of Israel in Bible, History, and Theology (Studies in Honour of Ed Noort; VTS 124), Leiden: Brill, 2009:373-387. 
and the foreign queen Jezebel, who was held responsible for the influence of Baal religion. Albertz shows there that was also a social conflict between traditional small landowners (like Nabot in $1 \mathrm{Ki} 21$ ) and the expanding class of officials related to the royal court. It was precisely this combination that was the reason why the conflict ended in massacres.

In the following centuries there were still controversies between those advocating the belief in the one god of Israel and the followers of other gods, but the conflicts were less violent. Monolatric reforms by Hezekiah and especially the one by Josia had great impact. They were carried through by state power. Cult installations were destroyed, priests lost their status, but there were no mass executions. Texts from the book of Deuteronomy related to this reform indicate that the change should not take place by killing the opponent but by changing him: "in Israel the violent fight against syncretism and for Yhwh monolatry, as we could see in the Jehu revolution, was step by step sublimated and internalized by law, education, and self-commitment". ${ }^{14}$

Characteristic of Biblical monotheism is according Albertz that its breakthrough as the belief in Yhwh as the only powerful ruler of the world occurred in a situation when this belief was not connected to any political power at all. It was the central message of the prophet we call Deutero-Isaiah, comforting his people in the Babylonian exile by claiming the superiority of their god. This lead to a new relation between monotheism, power and violence: "Increasing the power of Yhwh to the position of the only creator and ruler of the world did not involve any increase of political power of Israel; but it included the destruction of the world power of Babylon with its claim to absolute right (...) Thus the confession of monotheism, rightly understood, did not include violence against idolatry, but the resistance against the self-idolizing political power." ${ }^{\prime \prime}$ As a good example in our times of the positive influence of this belief in monotheism Albertz mentions how it helped his father who worked as a minister in the period of National Socialism in Germany: "At that time even the pure reciting of its wording: 'I am the Lord, your God, you shall not have any other gods beside of me' during the worship was a act of resistance. It denied the totalitarian claim of Adolf Hitler and uncovered the ideology of the German master race as self-idolization." 16

There is not much difference of opinion between Albertz and Assmann when it comes to the view on the potential of violence that comes along with the exclusive veneration of one god. Albertz is more positive with regard to the possibilities of a "responsible use of the monotheistic confession" taking some important clues from the rise of Yahwism, but his presentation of the history of Israelite monotheism in a kind evolutionary model is rather schematic and may be too positive. One could also say that the changing relation between monotheism and violence in the history of Israel was in the first place caused by the changing political power of the believers. Does not history show that as soon worshippers of the one god have the power (again) they are inclined to yield to the temptation to force their belief upon others or at least to make a sharp distinction between good and bad based on their majority view? One could also ask - with Assmann - whether this is not inherent to a belief in the one god who is a jealous god? And does not jealousy almost inevitable lead to violence?

\section{The Jealous and Avenging God of the Bible and Violence}

Against the view that the god of true monotheism is free of jealousy because he has no rivals Assmann rightly brings in that as a centerpiece of covenant theology Yhwh is

\footnotetext{
4 Alberts, Monotheism and Violence, 384.

Alberts, Monotheism and Violence, 385.

6 Alberts, Monotheism and Violence, 387.
} 
presented as a jealous god, who distinguishes between friend and foe. ${ }^{17}$ This is how he is presented in the Ten Commandments in Exodus 20 and then again, even more emphatically, in Exodus 34 telling the story of the stone tablets given for the second time to Israel. In Exodus 34 some important statements are given about the character of Yhwh. They are presented as words spoken by himself to Moses:

Yhwh passed before him, and proclaimed: Yhwh, Yhwh, a god merciful and gracious, slow to anger, and abounding in steadfast love and faithfulness, keeping steadfast love for the thousandth generation, forgiving iniquity and transgression and sin, yet by no means clearing the guilty, but visiting the iniquity of the parents upon the children and the children's children, to the third and the fourth generation (Ex 34:6-7).

Then Yhwh announces that he will make a covenant with the people of Israel, making the promise of giving them a land to live in, but also asking them their exclusive devotion. This has also consequences for the relations with other peoples:

Do not worship any other god, because Yhwh, whose name is jealous, is a jealous god. Be careful not to make a covenant with those who live in the land, for when they prostitute themselves to their gods and sacrifice to them, they will invite you and you will eat their sacrifices (Ex 34:14-15).

It is probably no coincidence that the repeated name of Yhwh in verse 6 has a counterpart in the repeated word 'jealous' (נקא) in verse 14. This appears to be typical of Yhwh and typical of his relation with his people. We find it also at the end of the book of Joshua where the covenant is renewed (Josh 24:19). It can be regarded as the negative side of Yhwh as a passionate god with very strong feelings for his people: "The outcome of a passion so intensely initiated has within it the seeds of intolerance, culminating in violence. (...) The God who has been madly in love becomes insanely jealous, which is Israel's deepest threat and most profound hope." Yhwh. It comes as no surprise that precisely both Elijah and Jehu indicate their extreme violence against Baal and his believers as "being zealous for Yhwh", using the same verb קנא (1 Ki 19:10) or noun related to it (2 Ki 10:16). Even more telling is the example of Phinehas according to Numbers 25. The story tells how the Israelites provoked their god by joining the Moabites in their worship of the god Baal, among other things by having sex with the Moabite women. Phinehas, one of the Aaronite priests, goes in front in fighting this idolatry. With his spear he pierces a copulating Israelite-Moabite couple. For this he praised by Yhwh, who says to Moses:

Phinehas, son of Eleazar, son of Aaron the priest, has turned back my wrath from the Israelites by manifesting such zeal (בקנאו) among them on my behalf that in my jealousy (קנאתי) I did not consume the Israelites. Therefore say, "I hereby grant him my covenant of peace. It shall be for him and for his descendants after him a covenant of perpetual priesthood, because he was zealous for his God, and made atonement for the Israelites" (Num 25:11-13).

So there is a direct relation with Yhwh's jealousy and the violent action taken by his priest. The best example of a jealous Yhwh in action himself is the vision of the prophet Nahum which opens with a beautiful but from a theological viewpoint not by everyone easily appreciated acrostic:

17 Assmann, Of God and Gods, 114

18 W Brueggemann, Theology of the Old Testament: Testimony, Dispute, Advocacy, Minneapolis: Fortress Press, 1997:384. 
Message about Nineveh, book of the vision of Nahum the Elkoshite.

A jealous and avenging God is Yhwh, Yhwh is avenging and a lord of wrath.

Yhwh takes vengeance on his adversaries and he rages against his enemies.

Yhwh is slow to anger but great in power and he will by no means clear the guilty.

$$
\begin{aligned}
& \text { משא נינוה ספר חזון נחום האלקשי }
\end{aligned}
$$

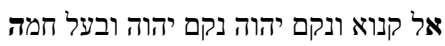

$$
\begin{aligned}
& \text { פקם יהוה לצריו ונוטר הוא לאיביו }
\end{aligned}
$$

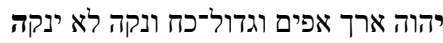

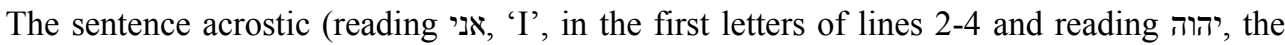
name of the god of Israel, at the end of lines 1-4, thus forming the well known formula 'I am Yhwh') indicates that we dealing here again with an important statement by Yhwh about himself. ${ }^{19}$ The jealous god in action is an avenging god. What follows in the book of Nahum is a description of how Yhwh settles with Assyria by destroying its capital Niniveh. This violence is presented as the rightful answer to the cruel violence exercised by the Assyrians upon their victims. The punishment of the Assyrians is that they now have to experience what they had done to others.

God's vengeance should not be confused with the often uncontrolled actions by humans seeking revenge. With Paul we should differentiate between human and God's revenge (Rom 12:19, quoting Deut 32:35). According to Jeremias there is a development from early texts in the Old Testaments speaking uninhabited of revenge as part of society (like Ex 21:20 and 1 Sam 14:24) to later texts speaking of God's vengeance as part of universal justice (like Isa 59:15b-20 and Nah 1:2). ${ }^{20}$

As may have become clear after reading first Exodus 34:6-7 and then Nahum 1:2-3 the prophet appears to quote the famous confession from the book of Exodus. ${ }^{21}$ Not the whole text about Yhwh is taken over, however: only the negative side of Yhwh who "by no means clears the guilty". Surprisingly, one finds the missing first part of Exodus 34:6-7 with the emphasis on the positive side of Yhwh as a merciful god quoted in the verses which in the book of the Twelve Prophets precede the prophecy of Nahum. ${ }^{22}$ Here, in the final verses of the book of Micah, the first part of the confession from Exodus 34 is quoted to give hope to the people after it was criticized severely and after the announcement of a heavy judgment. There may be hope, but this is totally dependent upon God's mercy:

Who is a God like you, pardoning iniquity

and passing over the transgression of the remnant of your possession?

He does not retain his anger forever,

because he delights in showing clemency.

He will again have compassion upon us;

he will tread our iniquities under foot.

19 See on the discussion about this and the following partial alphabetic acrostic K Spronk, 'The Line-Acrostic in Nahum 1: New Evidence from Ancient Greek Manuscripts and from the Literary Analysis of the Hebrew

Text', in: R de Hoop a.o. (eds.), The Impact of Unit Delimitation on Exegesis (Pericope 7), Leiden: Brill 2009, 228-240. A good survey of previous research and an interesting new interpretation is given by T Renz, 'A Perfectly Broken Acrostic in Nahum 1', JHS 9 (2009), article 23.

20 J Jeremias, 'Jhwh - ein Gott der 'Rache', in: C Karrer-Grube a.o. (eds.), Sprachen - Bilder - Klänge: Dimensionen der Theologie im Alten Testament und in seinem Umfeld (Fs R Bartelmus), Münster: UgaritVerlag, 2009:89-104.

21 Cf Jeremias, 'Jhwh - ein Gott der 'Rache', (100).

22 Cf K Spronk, 'Jonah, Nahum, and the Book of the Twelve: A Response to Jakob Wöhrle', JHS 9 (2009), article 8 . 
You will cast all our sins into the depths of the sea.

You will show faithfulness to Jacob

and unswerving loyalty to Abraham,

as you have sworn to our ancestors from the days of old (Mic 7:18-20).

These two quotations so close to each other of the same central text about Yhwh show how this text could be applied in different ways depending on the situation. In the book of Micah it is used to comfort people, indicating that the severe judgment is not Yhwh's final word. In the book of Nahum the emphasis not on the mercy of Yhwh but on his aversion to sin: there should be no doubt about it that Yhwh avenges evil. In this situation of oppression by the Assyrians there is no room for abounding love and faithfulness for the oppressors. He is 'good', however, "for those who wait for him and a stronghold in the day of distress" (Nah 1:7). ${ }^{23}$

In its turn the book of Jonah can be read as a reaction to the book of Nahum. Instead of the nationalistic view of Nahum the story of Jonah offers a more universal perspective. It shows again another side of Yhwh as having sympathy with all human beings, even when they are the citizens of the hated city of Niniveh. Again this new viewpoint is indicated by a different use of the traditional words from Exodus 34. When Jonah realizes that Niniveh is spared he reacts by referring to the well known confession:

But this was very displeasing to Jonah, and he became angry. He prayed to Yhwh and said,

"O Yhwh! Is not this what I said while I was still in my own country? That is why I fled to

Tarshish at the beginning; for I knew that you are a gracious god and merciful, slow to anger, and abounding in steadfast love, and ready to relent from punishing” (Jon 4:1-2).

There are clear correspondences between the books of Jonah and Nahum in the beginning and the end: both books are introduced as a prophecy concerning Niniveh, both end with a question. It is also intriguing that the turn in God's judgment on Niniveh according to the story in the book of Jonah is formulated as God "repenting (וינחם) over the evil he had said he who do upon them" (Jon 3:10), using the verb from which also the name of the prophet Nahum is derived.

With regard to the use of Exodus 34:6-7 the book of Jonah appears to be influenced by the book of Joel. Joel 2:12-14 is part of a prophecy addressed to the 'children of Zion' (2:23). It is a call for repentance, motivated by the quotation of the grace formula from Exodus 34:

Yet now, oracle of Yhwh, turn to me with all your heart,

and with fasting, and with weeping, and with lamentation;

and rend your heart, and not your garments,

and turn to Yhwh your God;

for he is gracious and compassionate,

slow to anger and abundant in mercy,

and repenting from doing evil.

Who knows whether he will not turn and repent,

and leave a blessing behind him,

even a meal-offering and a drink-offering unto Yhwh your God?

Jonah 4:2 also adds the phrase "and repenting from doing evil" to the quoted words from Exodus 34. This was already introduced in the book of Jonah in 3:10:

And God saw their works, that they turned from their evil way; and God repented of the evil, which he said he would do unto them; and he did it not.

23 See on the special place of this verse in the acrostic of Nahum 1 now Renz, A Perfectly Broken Acrostic, 22. 
It is hardly a coincidence that here the phrase is related to another important word from the text of Joel, namely the 'turning' to Yhwh, mentioned both at the beginning and the end of the oracle in Joel 2:12-14. As a matter of fact, the whole story of Jonah can be read as a narrative working out the oracle of Joel for a different audience. The people of Niniveh are doing exactly what Joel asked from his own people: they start fasting and mourning, to indicate their turning away from evil, hoping that in his turn God will repent (Jon 3:5-9).

The book of Jonah can be seen as a reaction to a one-sided negative theological view on foreign peoples, as is found in Joel 4:2 which states that all nations shall be judged because of their enmity against Israel. The writer of the book of Jonah builds his case upon the authoritative text from Exodus 34 as it is cited in Joel 2:13. He also took his inspiration, both in form and contents, from the book of Nahum. For this he had two reasons. First, like the book of Joel the confession from Exodus 34 also takes a central place in the book of Nahum. Secondly, it is the best illustration among the prophetic texts of a purely negative oracle against a foreign nation. The book of Nahum made him decide to use the notorious city of Niniveh as a fitting symbol for all hated foreign nations.

\section{Conclusion}

What does this survey of Biblical texts about Yhwh as the one god, the jealous and avenging god attribute to a healthy use of sacred scripture in the discussions about violence? At first sight it may seem that it only confirms that the Bible contains many different viewpoints in this matter. A closer look at the texts indicates that this problem is as old as the Bible itself and that it also contains indications how to handle this problem. The central confession of Exodus 34 about the character of Yhwh has been applied differently depending on the situation. It is also important to note that Yhwh is pictured in Exodus 34 both as merciful and as violent. One of the basic things in the belief in one god is that this indicates that there is a balance between these two sides. This can be regarded as a basis for trust for believers who experience that their life suffers from a constant disturbing of the balance. What also can be learned from this survey is that biblical texts which seem to picture a violent image of God should be read against their historical background. Within this framework it can be noted that there is not much difference between referring to Old Testament texts and New Testament texts. The picture of God has not basically changed, but what Paul writes in Romans 13 about the governing authorities and their right given by God to use the sword can only be fully understood when seen within the circumstances he was living.

The Biblical texts can help to open up discussions and to look critically from different perspectives at the situation of the reader. This also means that we should be aware not to avoid difficult discussions about types of violence that may come closer to our own situation, discussions about violence against other religions or about violence between nations. We should not shy away, for instance, to discuss domestic violence or clerical violence.

As it is broadly accepted as sacred text the Bible can function as an agent of change, provided that the reader engages him/herself in a dynamic reading process which asks of $\mathrm{him} /$ her to constantly re-evaluate the image of oneself and the enemy, in relation to God. 